\title{
PEMANFAATAN AMPAS TEBU SEBAGAI BAHAN PENGISI LEMBARAN SERAT SEMEN DALAM KAITANNYA TERHADAP MUTU
}

\author{
Nauval Huda, Erna Septiandini, Rosmawita
}

\begin{abstract}
Abstrak
Penelitian ini bertujuan untuk mengetahui apakah ampas tebu dapat dimanfaatkan sebagai bahan pengisi dalam pembuatan lembaran serat semen sehingga nantinya kuat lentur lembaran serat semen ampas tebu memenuhi standar kuat lentur SNI 15-0233-1989 (kuat lentur dan cara uji lembaran serat semen). Penelitian ini dilakukan di laboratorium Bio Komposit dan laboratorium Keteknikan Kayu Fakultas Kehutanan Institut Pertanian Bogor (PPB). Waktu pelaksanaan penelitian selama \pm 3 bulan, dari bulan Februari sampai dengan Mei 2007.

Metode yang digunakan dalam penelitian ini adalah metode eksperimental yang pelaksanaannya dilakukan di laboratorium. Populasi penelitian ini adalah lembaran serat semen yang menggunakan campuran 1 semen : 2 tepung batu : faktor air semen (fas) 0,9: ampas tebu dengan persentase $5 \%$, dan 10\% terhadap berat semen, jumlah masing-masing perlakuan sebanyak 15 buah, total populasi 435 buah. Sampel yang diambil sebanyak 12 buah untuk pengujian ukuran dan sifat-sifat physis melalui teknik acak secerhana.

Pengajuan persyaratan analisis data dengan pengujian normalitas menggunakan uji Liliefors pada taraf signifikan $\alpha=0,01$ sehingga data berdistribusi normal dan pengujian hipotesis menggunakan uji $\mathrm{T}$ pihak kiri dan pihak kanan dengan taraf signifikansi $\alpha=0,01$ dan $\mathrm{dk}=\mathrm{n}-1$.

Hasil dari penelitian ini adalah ampas tebu tidak dapat dimanfaatkan sebagai bahan pengisi lembaran serat semen sebab beberapa perlakuan yang dicobakan belum memenuhi standar kuat lentur yang disyaratkan SNI 150233-1989 (kuat lentur dan cara uji lembaran serat semen), terutama nilai kuat lentur.
\end{abstract}

Kata kunci : kuat lentur, ampas tebu dan lembaran serat semen

\begin{tabular}{|lcr|}
\hline Nauval Huda & Erna Septiandini, Ir..MT & Rosmawita Saleh, Dra,. MPd \\
Alumni Jurusan Teknik Sipil & Staf Pengajar Jurusan Teknik Sipil & Staf Pengajar Jurusan Teknik Sipil \\
Fakultas Teknik & Fakultas Teknik & Fakultas Teknik \\
Universitas Negeri Jakarta, 13220 & Universitas Negeri Jakarta, 13220 & Universitas Negeri Jakarta, 13220 \\
& & \\
& & \\
\hline
\end{tabular}

Pemanfaatan Ampas Tebu sebagai Bahan Pengisi Lembaran Serat Semen dalam Kaitannya terhadap Mutu Nauval Huda, , Erna Septiandini, Rosmawita Saleh 


\section{PENDAHULUAN}

Indonesia termasuk negara yang beriklim tropis maka sangat banyak tumbuh bermacam jenis tanaman dengan suburnya. Salah satu jenis tanaman yang tumbuh di Indonesia adalah tanaman tebu. Tanaman tebu ini diolah sebagai bahan baku pembuatan gula yang diproduksi untuk memenuhi kebutuhan masyarakat.

Dengan adanya industri gula, maka akan diperoleh hasil samping (limbah) yang diperoleh dari pengolahan gula tersebut adalah ampas tebu. Limbah dalam hal ini merupakan sisa pengolahan yang dibuang karena tidak bernilai ekonomis bahkan kadangkadang dapat menjadi polusi jika tidak dikelola secara tepat. Ampas tebu adalah bahan sisa berserat dari batang tebu yang telah mengalami ekstraksi niranya dan banyak mengandung jaringan dasar serta tidak tahan disimpan terlalu lama karena mudah terserang jamur. Sebagai hasil samping industri gula, ampas tebu mempunyai potensi yang sangat besar untuk bahan baku industri lainnya. Jumlah ampas tebu basah yang dihasilkan dari pabrik gula cukup besar, bisa mencapai 33-40 persen dari bobot tebu.

Pada umumnya ampas tebu banyak dimanfaatkan sebagai bahan bakar di pabrik gula, pembuatan kertas dan media budidaya jamur. Dengan perkembangan teknologi, limbah yang sekaligus berfungsi sebagai bahan baku untuk industri lainnya dapat ditingkatkan nilai ekonominya dengan cara mengolahnya menjadi produk yang bernilai jual cukup tinggi. Alternatif pengolahan yang cukup baik untuk dikembangkan adalah sebagai bahan pengisi di dalam pembuatan lembaran serat semen.

Penelitian tentang lembaran serat semen sudah pernah dilakukan, antara lain dengan menggunakan sabut kelapa (Drs. A. Luther Ola B.Sc dkk, 1995) dengan perbandingan $1 \mathrm{pc}: 2$ tepung batu : 5\%, 10\%, 15\% serat, ditinjau dari hasil pengujian, ternyata pemakaian serat 5\% memenuhi syarat kuat lentur dengan nilai kuat lentur 100,7 $\mathrm{kg} \mathrm{cm}^{2}$, ijuk dan sabut kelapa (Kus Lesmono, Universitas Negeri Jakarta, 1997), dengan perbandingan $1 \mathrm{pc}: 3$ tepung batu : 5\%,7,5\%,10\% serat hasil dari penelitian tersebut menjelaskan bahwa nilai kuat lentur maksimal diperoleh dari pemakaian serat sebanyak $10 \%$ yaitu sekitar $89,33 \mathrm{~kg} / \mathrm{cm}^{2}$, jerami (Cut Farida Hanum, UNJ, 2004) dengan perbandingan 1 pc : 3 tepung batu : 9\%, 10\%, 11\%, 12\% serat, hasil penelitian 
menjelaskan bahwa nilai kuat lentur maksimal diperoleh dari pemakaian serat sebanyak $10 \%$ yaitu sekitar $83,71 \mathrm{~kg} / \mathrm{cm}^{2}$.

Melihat dari hasil penelitian di atas, maka perlu diadakan penelitian tentang pemanfaatan ampas tebu sebagai bahan pengisi dalam pembuatan lembaran serat semen, sehingga dalam penelitian ini digunakan komposisi campuran yaitu 1 semen : 2 batu kapur : 5\%,7,5\%, 10\% serat dengan menguji terhadap kuat lentur dan cara uji lembaran serat semen. Penggunaan ampas tebu selain untuk pemanfaatan limbah industri gula dan efisiensi hasil pertanian, juga dapat digunakan sebagai bahan baku dalam pembuatan lembaran serat semen.

Berdasarkan latar belakang masalah tersebut di atas, maka timbul masalahmasalah sebagai berikut: Apakah ampas tebu dapat digunakan sebagai bahan pengisi dalam pembuatan lembaran serat semen? Apakah kuat lentur lembaran serat semen dengan pemanfaatan ampas tebu 5\%,7,5\%,10\% mempunyai nilai kuat lentur serta bobot isi lebih besar atau sama dengan $(\geq)$ kuat lentur lembaran serat semen standar SNI 150233-1989 dan nilai penyerapan air lebih kecil $(<)$ dari kuat lentur lembaran serat semen standar SNI 15-0233-1989? Bagaimana cara melakukan pengujian lembaran serat semen dengan menggunakan bahan pengisi ampas tebu? Bagaimana proses pembuatan lembaran serat semen dengan menggunakan ampas tebu? Apakah dengan memanfaatkan ampas tebu sebagai bahan pengisi pada pembuatan lembaran serat semen akan menghasilkan kualitas yang lebih baik?

Dari beberapa masalah yang timbul, maka perlu dibatasi supaya tidak menyimpang dari pokok permasalahan yang dibahas yaitu hanya mencakup pada aspek kuat lentur terutama kuat lentur, penyerapan air, dan bobot isi serta bentuk atau pandangan luar lembaran serat semen dengan memanfaatkan ampas tebu 5\%,7,5\%,10\% terhadap berat semen dengan panjang 1-2 cm an lolos ayakan 12 mesh dalam kaitannya dengan kuat lentur lembaran serat semen yang sesuai standar SNI 15-0233-1989.

\section{METODA}

Pemanfaatan Ampas Tebu sebagai Bahan Pengisi Lembaran Serat Semen dalam Kaitannya terhadap Mutu Nauval Huda, , Erna Septiandini, Rosmawita Saleh 


\section{METODA}

Tujuan penelitian ini adalah untuk mengetahui apakah ampas tebu dapat dimanfaatkan sebagai bahan pengisi dalam pembuatan lembaran serat semen dan kuat lentur yang dihasilkan memenuhi kuat lentur standar SNI 15-0233-1989 (tentang kuat lentur dan cara uji lembaran serat semen). Penggunaan ampas tebu sebagai bahan pembuatan lembaran serat semen ini, dalam upaya untuk memanfaatkan limbah industri gula dan efisiensi hasil pertanian.

Penelitian dilaksanakan di laboratorium Bio Komposit dan Keteknikan Kayu Fakultas Kehutanan Institut Pertanian Bogor (IPB) yang terletak di jalan Raya Darmaga Bogor, sedangkan lokasi pelaksanaan pekerjaan pembuatan bahan penelitian yang berupa lembaran serat semen ampas tebu dibuat di laboratorium Jurusan Teknologi Hasil Hutan Fakultas Kehutanan Institut Pertanian Bogor Bogor (IPB). Waktu pelaksanaan penelitian selama \pm 3 bulan, dari bulan Februari sampai dengan Mei 2007.

Metode yang akan dilakukan dalam penelitian ini adalah metode eksperimen yang pelaksanaannya dilakukan di laboratorium, di mana penelitian ini hanya melibatkan dua kelompok benda uji yaitu kelompok benda uji lembaran serat semen dengan bahan baku ampas tebu dan sebagai pembanding yaitu lembaran serat semen yang telah memenuhi standar kuat lentur (SNI 15-0233-1989 "Kuat lentur dan cara uji lembaran serat semen").

\section{Teknik Pengambilan Sampel}

1. Populasi

Populasi dalam penelitian ini adalah seluruh lembaran serat semen dengan bahan pengisi ampas tebu yang menggunakan campuran 1 semen : 2 tepung batu : fas 0,9 : persentase serat 5\%,7,5\%, 10\% di mana serat ampas tebu diambil dari berat semen. Populasi masing-masing persentase sebanyak 154 buah, jumlah seluruh populasi 45 buah.

2. Sampel

Untuk penarikan sampel masing-masing persentase $(5 \%, 7,5 \%, 10 \%)$ diambil sebanyak 12 buah. Dengan perincian 6 buah untuk pengujian bentuk atau pandangan lentur dan 6 buah untuk pengujian ukuran dan sifat-sifat physis. 


\section{Teknik Pengumpulan Data}

Data tentang pengujian kuat lentur lembaran serat semen yang meliputi; bentuk atau pandangan luar, ukuran dan sifat physis diambil dari hasil pengujian kuat lentur lembaran serat semen sesuai dengan SNI 15-0233-1989 tentang "kuat lentur dan cara uji lembaran serat semen" yang telah disesuaikan dengan perbandingan campuran serat ampas tebu.

Instrumen penelitian yang digunakan adalah berupa alat kempa untuk mengepres serat semen yang telah dicetak, mal cetakan pembentuk, sendok semen, timbangan, plat besi, tripleks, plastik dan peralatan lainnya untuk pengujian kuat lentur serta daftar isian yang digunakan untuk mengumpulkan data-data benda uji.

\section{Prosedur Pelaksanaan Penelitian}

1. Pekerjaan Persiapan

Sebelum dilakukan pembuatan lembaran serat semen perlu dilakukan persiapan baik alat maupun bahan. Alat terdiri dari alat timbangan, ember, sendok semen, mal cetakan, plastik, triplek dan alat kempa, sedangkan bahan terdiri dari semen, tepung batu, ampas tebu dan air. Setelah pekerjaan persiapan selesai kemudian dilakukan pemeriksaan bahan terhadap masing-masing bahan agar diketahui sifat dari bahan tersebut.

2. Pembuatan benda uji

a. Pembuatan benda uji lembaran serat semen dengan menggunakan perbandingan 1 semen : 2 tepung batu : fas 0,9 : persentase serat $5 \%, 7,5 \%, 10 \%$ (diambil sari berat semen).

b. Ukuran benda uji :

Uji kuat lentur $10 \times 25 \mathrm{~cm}$

Ukuran kerapatan air $10 \times 10 \mathrm{~cm}$

Uji bobot isi $5 \times 10 \mathrm{~cm}$

Untuk ketebalan dibuat $4 \mathrm{~mm}$

Pemanfaatan Ampas Tebu sebagai Bahan Pengisi Lembaran Serat Semen dalam Kaitannya terhadap Mutu Nauval Huda, , Erna Septiandini, Rosmawita Saleh 
c. Setelah ditentukan rencana perbandingan campuran dan semua bahan telah dipersiapkan, kemudian dilakukan pencampuran bahan, ketiga bahan tersebut dicampur lalu diaduk hingga merata dan ditambah air secukupnya hingga membentuk adonan yang matang dan homogen

d. Bahan-bahan yang telah diaduk dicetak pada cetakan, kemudian dipres dengan mesin kempa hingga rata. Setelah adukan dicetak dan dilepas dari cetakan, kemudian dikeringkan selama 24 jam.

e. Setelah dikeringkan selama 24 jam, lembaran serat semen direndam dalam air selama 1 minggu dengan tujuan reaksi hidrolis antara semen dan air bekerja dengan baik. Pemeliharaan selanjutnya lembaran serat semen disiram air hingga umur 28 hari. Setelah 28 hari lembaran serat semen dapat dilakukan pengujian.

3. Tahap Pengujian Terhadap Kuat lentur antara lain :

a. Penelitian pengujian bentuk atau pandangan luar lembaran serat semen

b. Penelitian pengujian kemampuan dipaku lembaran serat semen

c. Penelitian pengujian bobot isi lembaran serat semen

d. Penelitian pengujian kerapatan air lembaran serat semen

4. Tahap pengujian kuat lentur lembaran serat semen di laboratorium adalah sebagai berikut:

a. Dari setiap lembaran dipotong benda uji ukuran $25 \times 10 \mathrm{~cm}$

b. Sebuah dari padanya dipotong pada arah memanjang atau arah panjangnya mesin pembuat, dan sebuah lagi dipotong pada arah melebar atau arah lebarnya mesin pembuat.

c. Benda-benda uji kemudian dibersihkan dari serpih-serpih yang mudah lepas, lalu diukur lebarnya teliti sampai $1 \mathrm{~mm}$. Kemudian benda-benda uji dikerjakan pada suhu $60^{\circ} \mathrm{C}$ selama $2 \times 24$ jam

d. Setelah didinginkan dalam dexicator, benda-benda uji dilenturkan pada mesin pelentur (UTM INSTRON) dengan jarak tumpu $20 \mathrm{~cm}$ dan beban lentur pada bagian tengah 
e. Pisau penumpu dan pelentur bergaris tengah kurang lebih $30 \mathrm{~mm}$. Melalui pisau pelentur, benda uji dibebani lentur secara teratur dengan kecepatan kurang lebih 1 kg per detik, sampai benda uji patah

f. Bidang patahnya diukur tebalnya dan dihitung tebal rata-ratanya. Kuat lentur ditentukan dengan rumus

Kekuatan lentur $=\frac{3 \mathrm{pl}}{2 \mathrm{~b} \mathrm{~h}^{2}} \mathrm{~kg} / \mathrm{cm}^{2}$

Keterangan :

$\mathrm{p}=$ Beban patah $(\mathrm{kg})$

$\mathrm{I}=$ Jarak tumpu $(\mathrm{cm})$

$\mathrm{b}=$ Lebar benda uji $(\mathrm{cm})$

$\mathrm{h}=$ tebal benda uji $(\mathrm{cm})$

\section{Teknik Analisa Data}

Teknik analisa data yang digunakan dalam penelitian ini adalah menggunakan uji T (pihak kiri). Sebelumnya data diuji normalitasnya untuk mengetahui data berdistribusi normal atau tidak dengan menggunakan uji Liliefors.

\section{Hipotesis Statistik}

Hipotesis pertama

a. $H_{0}: \mu_{\mathrm{A}} \geq \mu \mathrm{M}$

Kuat lentur lembaran serat semen dengan memanfaatkan ampas tebu 5\%, 7,5\%, 10\% mempunyai nilai kuat lentur lebih besar atau sama dengan kuat lentur lembaran serat semen standar SNI 15-0233-1989.

Pemanfaatan Ampas Tebu sebagai Bahan Pengisi Lembaran Serat Semen dalam Kaitannya terhadap Mutu Nauval Huda, , Erna Septiandini, Rosmawita Saleh 
b. $H 1: \mu_{A}<\mu \mathrm{M}$

Kuat lentur lembaran serat semen dengan memanfaatkan ampas tebu 5\%, 7,5\%, 10\% mempunyai nilai kuat lentur lebih kecil dari kuat lentur lembaran serat semen standar SNI 15-0233-1989

Kriteria pengujian, Ho ditolak jika ttabel $>$ thitung

Dengan taraf signifikansi $\alpha=0,01$ dan $\mathrm{dk}=\mathrm{n}-1$

Hipotesis Kedua

a. $\mathrm{Ho}_{0}: \mu_{\mathrm{A}} \geq \mu \mathrm{M}$

Kuat lentur lembaran serat semen dengan memanfaatkan ampas tebu 5\%, 7,5\%, 10\% mempunyai nilai bobot isi lebih besar atau sama dengan kuat lentur lembaran semen standar SNI 15-0233-1989

b. $H 1: \mu_{A}<\mu \mathrm{M}$

Kuat lentur lembaran serat semen dengan memanfaatkan ampas tebu 5\%, 7,5\%, 10\% mempunyai nilai bobot isi lebih kecil dari kuat lentur lembaran serat semen standar SNI 15-0233-1989

Kriteria pengujian, Ho ditolak jika tabel $>$ thitung

Dengan taraf signifikansi $\alpha=0,01$ dan $\mathrm{dk}=\mathrm{n}-1$

Hipotesis Ketiga

a. $\mathrm{Ho}_{\mathrm{O}}: \mu_{\mathrm{A}}<\mu \mathrm{M}$

Kuat lentur lembaran serat semen dengan memanfaatkan ampas tebu 5\%, 7,5\%, 10\% mempunyai nilai penyerapan air lebih kecil dari kuat lentur lembaran serat semen standar SNI 15-0233-1989

b. $H 1: \mu_{A}>\mu \mathrm{M}$

Kuat lentur lembaran serat semen dengan memanfaatkan ampas tebu 5\%, 7,5\%, 10\% mempunyai penyerapan air lebih besar dari kuat lentur lembaran serat semen standar SNI 15-0233-1989 
Kriteria pengujian, Ho ditolak jika tabel $>$ thitung

Dengan taraf signifikansi $\alpha=0,01$ dan $\mathrm{dk}=\mathrm{n}-1$

\section{HASIL DAN PEMBAHASAN}

\section{Hasil Penelitian}

Dari penelitian yang telah dilakukan pada lembaran serat semen dengan beberapa perlakuan, yaitu A (lembaran serat semen yang memanfaatkan ampas tebu 5\%), B (lembaran serat semen yang memanfaatkan ampas tebu 7,5\%), C (lembaran serat semen yang memanfaatkan ampas tebu 10\%). Didapat data-data bentuk atau pandangan luar, ukuran panjang, lebar and tebal, kemampuan lengkap dipaku, bobot isi, penyerapan air, kerapatan air dan kuat lentur, secara lengkap hasil penelitian dapat dilihat sebagai berikut:

1. Hasil pengujian kadar air ampas tebu

Sebelum dilakukan pembuatan benda uji, terlebih dahulu melakukan pengujian kadar air ampas tebu. Dari hasil pengujian diperoleh kadar air ampas tebu rata-rata 8,86\%

2. Pengujian bentuk atau pandangan luar lembaran serat semen

3. Hasil pengujian panjang, lebar dan tebal lembaran serat semen

4. Hasil pengujian kemampuan dipaku dan digergaji lembaran serat semen

5. Hasil pengujian bobot isi dan penyerapan air lembaran serat semen

6. Hasil pengujian kerapatan air lembaran serat semen

7. Hasil pengujian kuat lentur lembaran serat semen

Dari pengujian kuat lentur lembaran serat semen diperoleh data-data sebagai berikut: Hasil pengujian kuat lentur lembaran serat semen

\begin{tabular}{|c|c|}
\hline Perlakuan & Kuat lentur $\left(\mathrm{kg} / \mathrm{cm}^{2}\right)$ \\
\hline $5 \%$ & 84,137 \\
$7,5 \%$ & 73,223 \\
$10 \%$ & 71,207 \\
\hline
\end{tabular}

Pemanfaatan Ampas Tebu sebagai Bahan Pengisi Lembaran Serat Semen dalam Kaitannya terhadap Mutu Nauval Huda, , Erna Septiandini, Rosmawita Saleh 


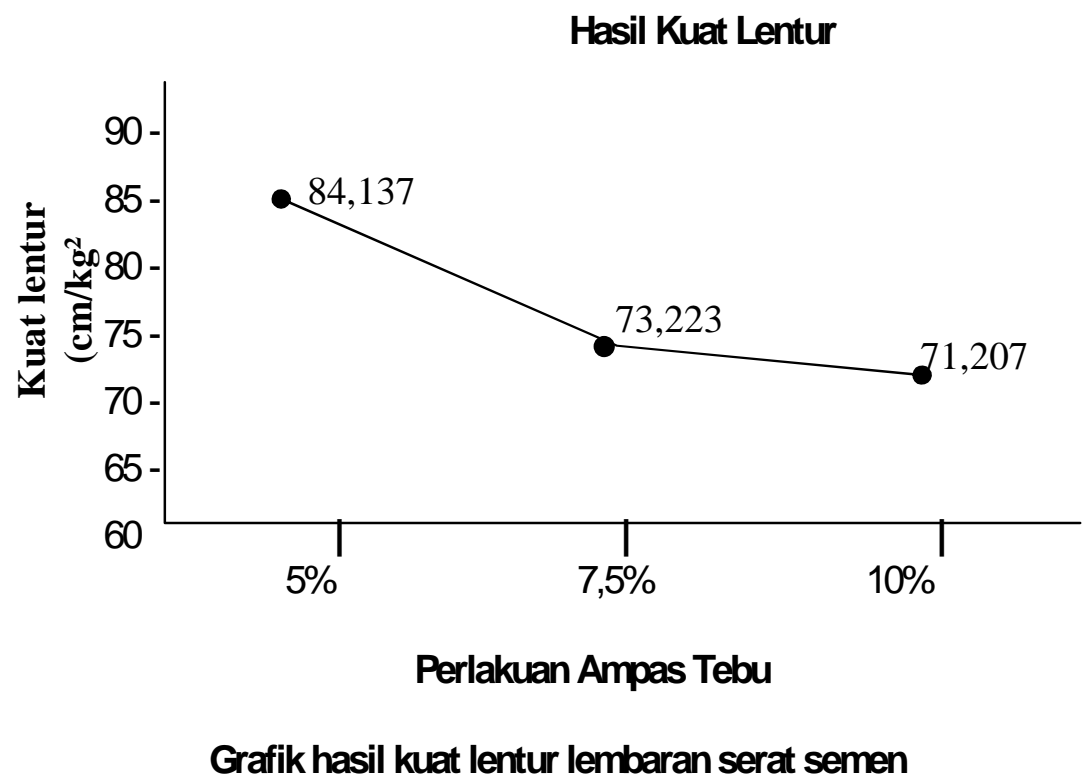

\section{Pengujian Persyaratan Analisis}

Untuk memenuhi syarat-syarat dalam pengujian hipotesis, terlebih dahulu dilakukan pengujian normalitas. Pengujian normalitas data dilakukan dengan menggunakan uji Liliefors.

Data yang dianalisa adalah nilai penyerapan air, bobot isi dan kuat lentur dari 3 perlakuan, yaitu $A$ (Lembaran serat semen dengan persentase 5\% ampas tebu), B (Lembaran serat semen dengan persentase 7,5\% ampas tebu), C (Lembaran serat semen dengan persentase $10 \%$ ampas tebu).

Analisa statistik yang digunakan untuk pengujian normalitas adalah menggunakan uji Liliefors.

Hasil pengujian normalitas dengan menggunakan rumus Lilliefors dari data kuat lentur kelompok $A$ (persentase 5\%) diperoleh $L 0=0,1783$ dan $L=0,364$, sehingga $L 0=$ $0,1783<\mathrm{L}=0,364$ dengan demikian data berdistribusi normal. Hasil pengujian normalitas dengan menggunakan rumus Lilliefors dari data kuat lentur kelompok $B$ (persentase 7,5\%) diperoleh $L 0=0,1564$ dan $L=0,364$, sehingga $L O=0,1564<L=0,364$ dengan demikian data berdistribusi normal. Hasil pengujian normalitas dengan menggunakan rumus 
Lilliefors dari data kuat lentur kelompok $C$ (persentase 10\%) diperoleh $L 0=0,2258$ dan $L=$ 0,364 , sehingga $L 0=0,2258<L=0,364$ dengan demikian data berdistribusi normal.

\section{Pengujian Hipotesis}

Hasil pengujian hipotesis dengan menggunakan uji T dari data kuat lentur kelompok $A$ (persentase 5\%) diperoleh ttabel $=3,365$ an thitung $=-16,253$, sehingga tabel $=3,365>$ thitung $=-16,253$. Karena kriteria pengujian Ho ditolak jika tabel $>$ thitung dengan taraf signifikan $\alpha=$ 0,01 dan $\mathrm{dk}=\mathrm{n}-1$ maka Ho ditolak. Kesimpulannya kuat lentur lembaran serat semen dengan memanfaatkan ampas tebu 5\% mempunyai nilai kuat lentur lebih kecil dari kuat lentur lembaran serat semen standar SNI 15-0233-1989. Hasil pengujian hipotesis dengan menggunakan uji T dari data kuat lentur kelompok B (persentase 7,5\%) diperoleh tabel $=$ 3,365 dan thitung $=-19,805$, sehingga tabel $=3,365>$ thitung $=-19,805$. Karena kriteria pengujian Ho ditolak jika tabel $>$ thitung dengan taraf signifikan $\alpha=0,01$ dan $\mathrm{dk}=\mathrm{n}-1$ maka Ho ditolak. Kesimpulannya kuat lentur lembaran serat semen dengan memanfaatkan ampas tebu 7,5\% mempunyai nilai kuat lentur lebih kecil dari kuat lentur lembaran serat semen standar SNI 15-0233-1989. Hasil pengujian hipotesis dengan menggunakan uji T dari data kuat lentur kelompok $C$ (persentase 10\%) diperoleh tabel $=3,365$ an thitung $=$ 22,477 , sehingga tabel $=3,365>$ thitung $=-22,477$. Karena kriteria pengujian Ho ditolak jika $t_{\text {tabel }}>t_{\text {hitung }}$ dengan taraf signifikan $\alpha=0,01$ dan $\mathrm{dk}=\mathrm{n}-1$ maka Ho ditolak. Kesimpulannya kuat lentur lembaran serat semen dengan memanfaatkan ampas tebu 10\% mempunyai nilai kuat lentur lebih kecil dari kuat lentur lembaran serat semen standar SNI 15-0233-1989.

\section{Pembahasan Hasil Penelitian}

Data lengkap hasil penelitian menunjukkan bahwa sebagian perlakuan yang dicobakan belum memenuhi syarat kuat lentur lembaran serat semen berdasarkan SNI 150233-1989. Dengan memanfaatkan ampas tebu 5\%,7,5\%, 10\% pada pengujian bentuk atau pandangan luar diperlakukan 10\% menunjukkan bahwa permukaan lembaran kurang rata, pada pengujian kemampuan dipaku rata-rata tiap perlakuan menunjukkan kurang baik kemampuan dipakunya, sedangkan pada hasil pengujian kemampuan digergaji dan

Pemanfaatan Ampas Tebu sebagai Bahan Pengisi Lembaran Serat Semen dalam Kaitannya terhadap Mutu Nauval Huda, , Erna Septiandini, Rosmawita Saleh 
kerapatan air rata-rata tiap perlakuan memenuhi persyaratan. Hasil pengujian terhadap ukuran panjang, tebal, dan lebar tidak menunjukkan penyimpangan ukuran yang berarti.

Ditinjau dari penyerapan air lembaran serat semen dengan memanfaatkan ampas tebu 5\%,7,5\%, dan 10\% menghasilkan nilai masing-masing 19,702\%, 20,062\%, 20,796\%, namun masih sesuai dengan SNI 15-0233-1989 yaitu maksimum 35\%. Pengujian ini menunjukkan bahwa semakin banyak jumlah ampas tebu menyebabkan penyerapan air semakin besar pula, hal ini disebabkan oleh sifat tepung batu dan ampas tebu yang dapat menyerap air sehingga makin banyak butiran air yang terperangkap di dalamnya.

Nilai bobot isi lembaran serat semen dengan memanfaatkan ampas tebu 5\%, 7,5\%, dan $10 \%$ menghasilkan nilai masing-masing $2,043 \mathrm{gr} / \mathrm{cm}^{3}, 2,018 \mathrm{gr} / \mathrm{cm}^{3}, 1,993 \mathrm{gr} / \mathrm{cm}^{3}$ menunjukkan adanya penurunan kuat lentur namun masih sesuai dengan SNI 15-02331989 yaitu minimum 1,2 $\mathrm{gr} / \mathrm{cm}^{3}$. Hal ini disebabkan makin besar ampas tebu yang digunakan maka semakin banyak rongga-rongga yang terbentuk, sehingga nilai bobot isi menjadi lebih ringan.

Hasil pengujian terhadap kuat lentur lembaran serat semen dengan memanfaatkan ampas tebu 5\%,7,5\%, dan 10\% menghasilkan nilai 84,137 kg/cm², 73,223 kg/cm², 71,207 $\mathrm{kg} / \mathrm{cm}^{2}$. Hal ini menunjukkan bahwa nilai kuat lentur berada di bawah nilai minimum kuat lentur rata-rata menurut SNI 15-0233-1989 yaitu $100 \mathrm{~kg} / \mathrm{cm}^{2}$. Nilai kuat lentur yang dicapai semua perlakuan berada di bawah standar kuat lentur disebabkan oleh pemakaian ampas tebu yang terlalu banyak $(5 \%, 7,5 \%, 10 \%)$ menyebabkan daya ikat semen menurun dan lembaran menjadi kurang kuat.

Glaser and Stranss, 1980, The Discovery of Grounded Theory : Strategis for Qualitative Research, , Aldine Publishing, Co, New

\section{KESIMPULAN}

1. Dengan memanfaatkan ampas tebu $5 \%, 7,5 \%$, dan $10 \%$, nilai kuat lentur lembaran serat semen yang dihasilkan masih berada di bawah nilai kuat lentur lembaran serat 
semen yang dihasilkan masih berada di bawah nilai standar kuat lentur SNI 15-02331989 yaitu rata-rata minimal $100 \mathrm{~kg} / \mathrm{cm}^{2}$.

2. Makin banyak menggunakan ampas tebu, maka nilai penyerapan air lembaran serat semen makin besar pula.

3. Manfaat ampas tebu yang semakin banyak menyebabkan lembaran serat semen menjadi lebih ringan.

4. Dengan memanfaatkan ampas tebu $5 \%, 7,5 \%$, dan $10 \%$ terhadap berat semen serta kadar air 8,86\% pada pembuatan lembaran serat semen yang menggunakan campuran 1 pc : 2 tepung batu menunjukkan pengujian terhadap bobot isi, penyerapan air, kerapatan air, ukuran, bentuk atau pandangan luar, kemampuan digergaji dan dipaku memenuhi standar kuat lentur SNI 15-0233-1989 kecuali nilai kuat lentur.

\section{DAFTAR PUSTAKA}

Balai Penelitian Bahan. Petunjuk Teknis Proses Pembuatan Serat Semen. Jakarta: Dinas Perindustrian DKI Jakarta, 1996.

Dumanauw, J.F. Mengenal Kayu. Semarang: Penerbit Kanisius, 1993.

Joesoef, Mochamad,. Pengaruh Komposisi Campuran Kayu Sengon dan Ampas Tebu, dan Jumlah Urea Formaldehida terhadap Sifat dan Mekanik Particleboard. Yogyakarta: Fakultas Kehutanan Universitas Gajah Mada, 1980.

Mulyono, Tri. Teknologi Beton. Jakarta: Universitas Negeri Jakarta, 1999.

Program Semi Que V. Pedoman Penulisan Skripsi. Jakarta: Universitas Negeri Jakarta, 2003.

Pusat Penelitian Perkebunan Gula Indonesia (P3GI). Particle Board dari Ampas Tebu. Pasuruan: Berita No. 12, 1995.

Silvianty. Kajian Peluang Pendirian Industri Papan Partikel Berdasarkan Potensi Bahan Baku Ampas Tebu di Daerah Cirebon Jawa Barat. Bogor: Institut Pertanian Bogor, 1994.

SNI 15-0233-1989. Kuat lentur dan Cara Uji Lembaran Serat Semen. Badan Standariassi Nasional, 1989.

Syaefudin. Teknologi Bahan. Bandung: Angkasa, 1996.

$$
\begin{array}{r}
\text { Pemanfaatan Ampas Tebu sebagai Bahan Pengisi Lembaran Serat Semen } \\
\text { dalam Kaitannya terhadap Mutu } \\
\text { Nauval Huda, , Erna Septiandini, Rosmawita Saleh }
\end{array}
$$


Saiman. Studi Pemanfaatan Ampas Tebu sebagai Bahan Papan Partikel Kaitannya dengan Kerapatan dan Kekuatan Lentur Standar. Jakarta: Universitas Negeri Jakarta, 1997.

Sudjana. Metoda Statistika. Bandung: Penerbit Tarsito, 1995.

Supribadi, I.K. Ilmu Bangunan Gedung. Bandung: Armico, 1996. 